\title{
К вопросу о карбонатитовом штоке Хибин: могут ли быть найдены алмазы на дне Умбозера?
}

\section{Каменский И.Л.}

Геологический институт КНЦРАН, Anamumb, iglkam@mail.ru

Аннотация. Карбонатитовый шток Хибин - небольшое тело, сложенное карбонатитовой брекчией измененных фойяитов, ийолитов и других пород, рассекаемых штокверком поздних мангандоломитовых и мангананкеритовых жил. Комплексный анализ геологии района продолжает порождать нетривиальные гипотезы, одна из которых изложена в данной статье: Возможно, карбонатитовый шток представляет собой небольшой останец гигантского карбонатитового тела, ранее находившегося в районе современного озера Умбозера, разделяющего Хибинский и Ловозерский щелочные интрузии. Карбонатит мог содержать акцессорные алмазы, которые в настоящее время покоятся в донных отложениях Умбозера.

Ключевые слова: карбонатиты, Хибины, Кольский полуостров.

\section{On the issue of the Khibiny carbonatite stock: is it possible to find diamonds on the bottom of Lake Umbozero?}

\author{
Kamensky I.L. \\ Geological Institute FRC KSC RAS, Apatity, iglkam@mail.ru
}

\begin{abstract}
The Khibiny carbonatite stock is a minor body composed of carbonatite breccia of unaltered foyaites, ijolites and other rocks cut by a stockwork of late mangandolomite and mangankerite veins. Comprehensive analyses of the regional geology have been providing non-trivial hypotheses. One of them is highlighted in the current article, i.e. a carbonatite stock is presumed to be a minor remnant of a giant carbonatite body that used to be in the area of present-day Lake Umbozero, dividing the Khibiny and Lovozero alkaline massifs. Carbonatite could contain accessory diamonds that currently rest in bottom sediments of Umbozero.
\end{abstract}

Key words: carbonatites, Khibiny, Kola Peninsula.

\section{Введение}

В конце 70-х годов прошлого столетия в пределах крупнейшего в мире Хибинского массива агпаитовых нефелиновых сиенитов и ийолит-уртитов было открыто штокообразное тело карбонатитов и карбонатизированных силикатных пород. В 1978 г. гравиметрической съемкой на западном берегу оз. Умба была обнаружена небольшая аномалия силы тяжести, имевшая в плане форму эллипса размером $1 \times 2$ км. Поисковое бурение в 1979-1980 гг. выявило на этом участке шток карбонатитовой брекчии сечением до 800 м. Карбонатитовый комплекс обнаружен под мощным сорокаметровым чехлом рыхлых отложений у восточной границы Хибинского массива на продолжении выклинивания серповидных в плане тел рисчорритов и ийолит-уртитов. В дальнейшем выяснилось, что карбонатитовые жилы и их штокверки распространены в Хибинах далеко за пределами карбонатитового ядра (Минаков и др., 1981; Дудкин и др., 1984).

Открытие в Хибинах карбонатитов поставило ряд вопросов, выходящих за рамки изучения только самого карбонатитового штока и окружающих его пород. Данные по изучению карбонатитов и комплексный анализ геологии района порождает нетривиальные гипотезы, которые могут показаться невероятными, одна из которых изложена в данной статье.

\section{Карбонатитовый шток Хибин - каков был его первоначальный размер?}

Исследования показали, что карбонатитовый шток (рис. 1) прорывает фойяиты, т.е. вместе с сопровождающими его дайками является наиболее молодым образованием в Хибинах (Боруцкий, 2010). Карбонатитовый шток представляет собой карбонатитовую брекчию измененных фойяитов и ийолитов, лампрофиров, тингуаитов и щелочных трахитов, слюдитов, биотит-кальцитовых, альбиткальцитовых и пироксен-кальцитовых с апатитом карбонатитов, рассекаемых штокверком поздних 

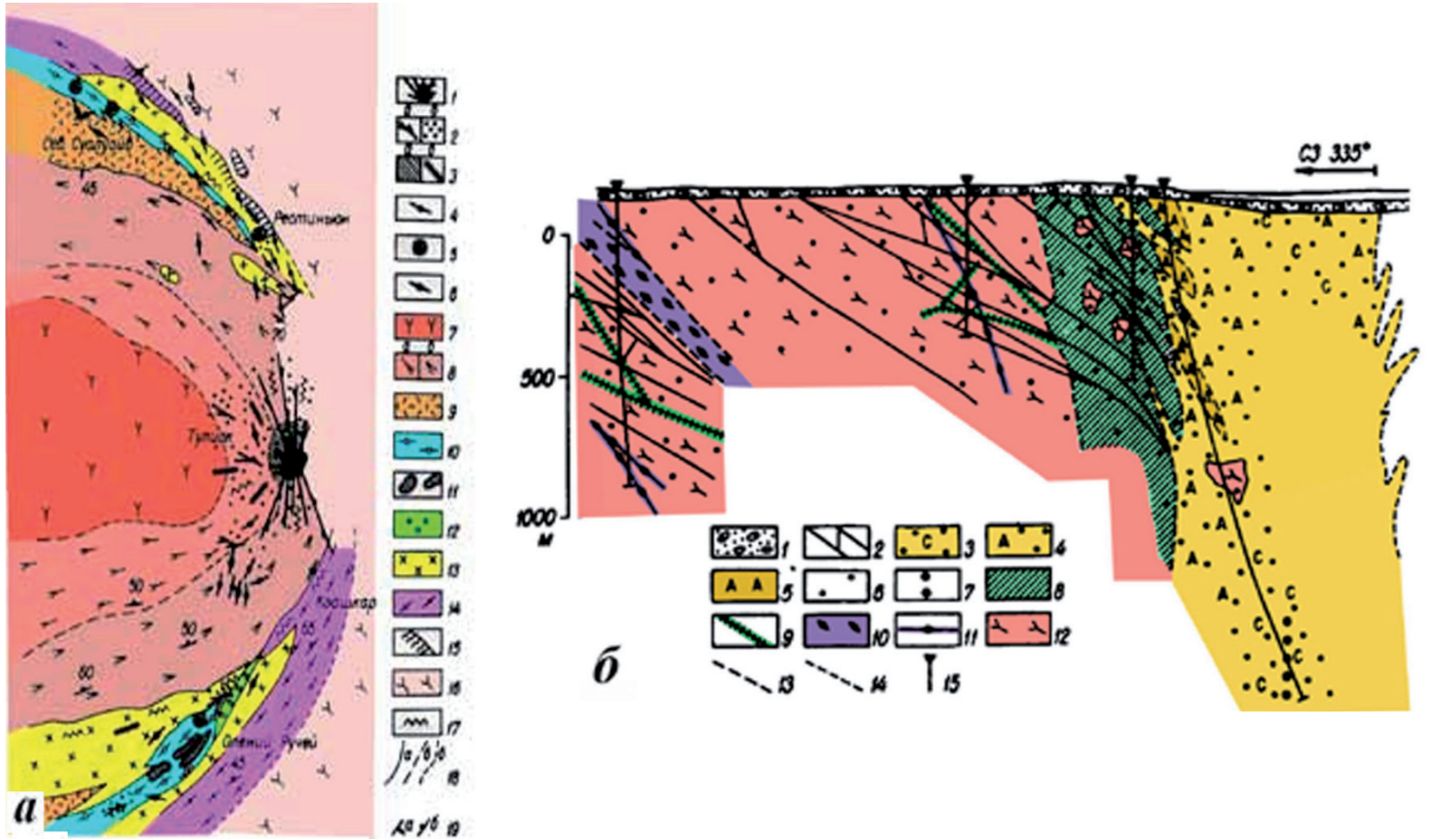

Рис. 1. Карбонатиты в Хибинском массиве (Дудкин и др.,1984; Боруцкий, 2010).

а - в плане. 1 - карбонатитовый шток; 2 - штокверки карбонатитовых жил (а) и карбонатизация силикатных пород (б); 3 - брекчия с тингуаитовым цементом (а) и отдельные дайки тингуаитов (б); 4 - эгиринальбитовые жилы; 5 - эруптивно-эксплозивные брекчии (трубки взрыва); 6 - дайки лампрофиров; 7 - массивные эгириновые фойяиты; 8 - трахитоидные фойяиты: эгирин-арфведсонитовые (а) и арфведсонитовые (б); 9 - лявочорриты (среднезернистые эгириновые нефелиновые сиениты); 10 - ийолиты трахитоидные; 11 - апатито-нефелиновые породы; 12 - уртиты массивные; 13 - рисчорриты; 14 - хибиниты трахитоидные; 15 - щелочные и нефелиновые сениты краевой зоны массива; 16 - фенитизированные гранито-гнейсы архея; 17 - зоны смятия и катаклаза; 18 - границы пород: интрузивные (а), петрографических разностей (б) и предполагаемые (c); 19 элементы залегания: контактов (а), трахитоидности и полосчатости (б). б - в разрезе: 1 - четвертичные отложения; 2 - карбонатные жилы в силикатных породах; 3 - карбонатитовая брекчия с преобладанием биотит-кальцитовых карбонатитов и слюдитов; 4 - карбонатитовая брекчия с преобладанием альбит-кальцитовых карбонатитов; 5 - кальцит-альбитовые породы; 6 - наложенная карбонатизация силикатных пород; 7 - пироксен-кальцитовые карбонатиты, обогащенные апатитом; 8 - тингуаиты, брекчирующие фойяиты; 9 - дайки тингуаитов; 10 - мощная дайка лампрофира, брекчирующая фойяит; 11 - мелкие дайки лампрофиров; 12 - фойяиты; 13 - условные границы пород; 14 - проблематичные границы штока карбонатитовой брекчии; 15 - буровые скважины.

Fig.1. Carbonatites in the Khibiny massif (Dudkin et al.,1984; Borutsky, 2010).

a - in plan: 1 - carbonatite stockwork; 2 - stockworks of carbonatite veins (a) and carbonatized silicate rocks (b); 3 - breccia with tinguaite cement (a) and individual tinguaite dykes (b); 4 - aegirine-albite veins; 5 - eruptiveexplosive breccias (explosion pipes); 6 - lamprophyre dikes; 7 - massive aegirine foyaites; 8 - trachytoid foyaites: aegirine-arfvedsonite (a) and arfvedsonite (b); 9 - lyavochorrites (medium-grained aegirine-nepheline syenites); 10 - trachytoid ijolites; 11 - apatite-nepheline rocks; 12 - massive urtites; 13 - rischorrites; 14 - trachytoid khibinites; 15 - alkaline and nepheline syenites of the massif rimming; 16 -fenitized Archaean granite gneisses; 17 - zones of folding and cataclasis; 18 - boundaries of rocks: intrusive (a), petrographic varieties (b) and presumed (c); 19 bedding elements of: contacts (a), trachytoid structure and banding (b). b - in section: 1 - Quaternary sediments; 2 - carbonate veins in silicate rocks; 3 - carbonatite breccia with dominant biotite-calcite carbonatites and glimmerites; 4 - carbonatite breccia with dominant albite-calcite carbonatites; 5 - calcite-albite rocks; 6 - imposed carbonatisation of silicate rocks; 7 - pyroxene-calcite carbonatites enriched with apatite; 8 - tinguaites brecciating foyaites; 9 - tinguaite dikes; 10 - thick lamprophyre dike brecciating foyaite; 11 - minor lamprophyre dikes; 12 - foyaites; 13 - conditional rock boundaries; 14 - problematic boundaries of the carbonatite breccia stock; 15 - bore holes. 
мангандоломитовых и мангананкеритовых жил. К северу и западу от карбонатитового штока вскрыты тингуаиты и щелочные трахит-порфиры с ксенолитами измененных фойяитов и лампрофиров (эруптивная брекчия с тингуаитовым цементом, 300-400 м), рассекаемых жилами карбонатитов. И в ареале окружающих карбонатизированных фойяитов всё это сопровождается серией даек лампрофиров, тингуаитов, щелочных трахитов и многочисленных альбитовых, эгирин-альбитовых и карбонатных жил (Боруцкий, 2010).

Каков первоначально (365 млн. лет тому назад) был размер карбонатитовой массы, от которой, по образному выражению Ф.П. Митрофанова, к настоящему времени остался только «хвостик» - карбонатитовый шток Хибин, вскрытый на дне заливчика Тулийлухт в западной части Умбозера?

Вернемся на десяток лет назад, когда в стенах Геологического института КНЦ РАН профессор МГУ Эрнст Максович Спиридонов делал доклад о минерале икаите (гидрокальцит $\mathrm{CaCO}_{3} * 6 \mathrm{H}_{2} \mathrm{O}$ ). Этот минерал образуется в условиях холодного климата и является климатическим индикатором. Заметим тут попутно, что первым, кто правильно разобрался в структуре этого минерала, был сотрудник ВНИГРИ, Каплан Михаил Ефимович (Юдович, 2008). Доклад вызвал большой интерес, и дискуссия после доклада перешла на более широкий круг вопросов, касающихся карбонатов вообще и карбонатитов в частности. Э.М. Спиридонову, среди прочих, был задан вопрос: «Возможно ли, что первоначально, т.е. 365 лет тому назад, всё то пространство (или часть его), которое сейчас занимает вода Умбозера, было заполнено карбонатитом, а к настоящему времени он весь растворился и унесен в виде раствора и от всего исходного великолепия остался только карбонатитовый шток Хибин?». В своем ответе на этот вопрос Э.М. Спиридонов предположил, что карбонатитовый шток - это «макушечка, волосок» более крупного тела карбонатитов, находящегося ниже. Феликс Петрович Митрофанов тут же возразил: «Нет, никакая это не макушечка, это «хвостик» (если иметь в виду хвостик слона) первоначально существовавшего массива карбонатитов». Ф.П. Митрофанов поддержал мысль о том, что исходная масса карбонатита была значительно больше, но высказал предположение, что значительная часть его не сохранилась. То есть существование громадного карбонатитового массива, по мнению академика Ф.П. Митрофанова было реальным.

Замечено, что все карбонатитовые участки девонских интрузий на Кольском полуострове в рельефе выражены его понижением (Афанасьев, 2011), а шток Хибин рекордсмен в этом качестве на дне заливчика в западной части Умбозера. В составе его присутствует содовая (натровая) составляющая, что и делает его гораздо легче растворимым по сравнению с другими карбонатами. В работе (Минаков и др., 1981) приведен вещественный состав вскрытого скважиной, так называемого, карбонатитового ядра Хибин. Он имеет существенную натровую составляющую, что и способствует его растворению. И за прошедшие 300 с лишним миллионов лет остался только этот «хвостик». Установить, какого размера была эта карбонатитовая масса в исходном состоянии, с нашей точки зрения, является задачей вполне соответствующей академическому статусу Геологического института и попытаться ее решить можно было бы по акцессориям этого гипотетического исчезнувшего массива, которые обязаны находиться на дне Умбозера.

Наиболее ярким компонентом среди акцессориев мог бы быть алмаз. Сегодня уже признано, что кимберлитовый расплав не является единственно возможным транспортным средством для алмазов. Эту функцию может выполнять и карбонатитовый поток с существенно меньшей температурой. Это признаётся, в частности, в работах (Когарко, Рябчиков, 2013; Владыкин, 2008). Кроме того, Андрей Васильевич Ефимов (первооткрыватель архангельских алмазов) подтвердил это в устной беседе ещё в 1990 году.

Можно предположить, что на дне Умбозера могут находиться алмазы. Они могут там присутствовать, если первоначально (365 млн. лет тому назад) являлись акцессорной примесью карбонатитовой массы, заполнявшей пространство, занятое сейчас водой Умбозера.

Представляется, что здесь уместно вспомнить результаты изучения изотопов гелия в коллекции алмазов, приведенные в работе (Каменский, Толстихин, 1992). Среди прочих, там был изучен кристалл (размером в 1 карат) из предуральских россыпей, в последних температурных ступенях которого изотопное отношение ${ }^{3} \mathrm{He} /{ }^{4} \mathrm{He}$ было очень высоким (солнечным). По словам А.В. Ефимо- 
ва, рассыпные алмазы Предуралья - большая загадка: нет даже предположений, где они были в коренном залегании. А что, если их транспортировал карбонатитовый расплав с содовой составляющей и к настоящему времени от карбонатитового массива и следов не осталось?

\section{Заключение}

Все карбонатитовые комплексы девонских интрузий Кольского полуострова выражены в рельефе его понижением (Афанасьев, 2011), хибинские карбонатиты являются рекордсменами в этом отношении из-за своего состава с существенной содовой/натровой составляющей. Если удастся доказать, что первоначально (360 млн. лет тому назад) карбонатиты занимали место, занятое сейчас водой Умбозера, то они тем самым объединят Хибины и Ловозеро, и составят вместе с ними один, самый грандиозный для Земли массив щёлочно-ультраосновных пород. Гипотезу о том, что Хибинский и Ловозерский массивы произошли из одного источника и представляли из себя лакколит Андрей Васильевич Ефимов высказывал в частных беседах с автором этой статьи в ещё конце прошлого века. В заключение хочется привести очень уместную цитату из работы (Владыкин, 2008): «То, что их нет в настоящее время, ещё не значит, что их не было».

\section{Литература}

1. Афанасьев Б.В. Минеральные ресурсы щёлочно-ультраосновных массивов Кольского полуострова. СПб. Изд-во: Роза ветров. 2011. 224 с.

2. Боруцкий Б.Е. Современные представления о природе и геологической истории формирования пород Хибинского щелочного массива (критическое сопоставление предлагавшихся гипотез и комментарии к ним) // Матер. Всерос. (с междун. участием) научно-практической конференции, посвящённой 80-летию Кольского НЦ РАН. Геологический институт КНЦ РАН, Кольское отделение РМО, Апатиты, 2023 июня 2010 . Апатиты. Изд-во: К\&М. 2010. С. 7-30.

3. Владыкин Н.В. Формационные типы карбонатитов, их геохимия и генезис // Труды VIII Международного семинара «Глубинный магматизм, его источники и плюмы». Иркутск. 2008. С. 49-51.

4. Дудкин О.Б., Минаков Ф.В., Кравченко М.П., Кравченко Э.В., Кулаков А.Н., Полежаева Л.И., Припачкин В.А., Пушкарев Ю.Д., Рюнгенен Г.И. Карбонатиты Хибин. Апатиты. Изд-во: КФАН СССР. 1984. 98 с.

5. Каменский И.Л., Толстихин И.Н. Высокие отношения $\mathrm{He}^{3} / \mathrm{He}^{4}$ в алмазах: ограничения на возраст аллювия // Геохимия. 1992. № 4. С. 561-569.

6. Когарко Л.Н., Рябчиков И.Д. Алмазоносность и окислительный потенциал карбонатитов // Петрология. 2013. Т. 21. № 4. С. 350-371.

7. Минаков Ф.В., Дудкин О.Б., Каменев Е.А. О карбонатитовом комплексе Хибин // ДАН. 1981. Т. 259. № 3. С. 672-675.

8. Юдович Я.Э. Загадка кальцитовых псевдоморфоз Судьба открытия Миши Каплана // Вестник Института геологии Коми НЦ УрО РАН. 2008. № 6. С. 15-17. https://cyberleninka.ru/article/n/zagadka-kaltsitovyhpsevdomorfoz. 